\title{
UM MANUSCRITO, DOIS OLHARES SENSÍVEIS E UMA VIAGEM...
}

\author{
Resenha do livro \\ Um estudo sobre "versos para pequeninos", manuscrito de João Köpke, \\ de Norma Sandra de Almeida Ferreira (Campinas, Mercado de Letras, 2017)
}

Flávia Poliana Serafim Alves

Universidade Estadual de Campinas flavia91alves@gmail.com

"Versos para os pequeninos, de forma mais contundente do que em suas obras editadas, oferece outra faceta de João Köpke, a de um escritor que busca conquistar a criança-leitora por uma representação do universo infantil, que com travessuras, questiona o conhecimento, a verdade, a realidade." (p.159)

Esta obra foi escrita por Norma Sandra de Almeida Ferreira, professora livre docente da Faculdade de Educação da Universidade Estadual de Campinas e integrante do grupo de pesquisa Alfabetização, Leitura e Escrita (ALLE), tendo como objetivo analisar e explorar a configuração composicional de um manuscrito, não publicado, destinado a leitores infantis, elaborado por João Köpke (18521926), educador, autor de livros escolares, além de defensor dos princípios positivistas e método intuitivo e intelectual republicano do século XIX.

No início do livro, a autora relata como recebeu o manuscrito de João Köpke pelas mãos de uma de suas herdeiras. Em seguida, somos conduzidos a uma breve biografia do autor e ao contexto histórico no qual ele se insere.

Para Ferreira, no final do século XIX e início do século XX, as obras infantis tinham como propósito educar moral e intelectualmente a criança de modo adequado, segundo os valores dos adultos, sendo comum nessa época textos que veiculassem uma moral e a linguagem dita correta. É nesse contexto que João Köpke escreve seu manuscrito Versos para os pequeninos, composto por 24 poemas acompanhados de 24 estampas (ilustrações). Cada estampa é posicionada na página esquerda e, na direita, dispõe-se o poema. Para João Köpke, as estampas eram importantes, pois permitiam a expressão dos sentimentos e ideias contidas nos versos e antecediam a leitura a ser feita pelos leitores.

Os poemas do autor tinham a brincadeira como principal tema, apresentando uma infância que vive uma fase distinta da do adulto - uma fase em que as crianças brincam, felizes e ingênuas. O autor também utiliza em seus poemas a reprodução da fala infantil, demonstrando estar preocupado com os modos distintos de comunicação que fazem parte do universo infantil.

No intuito de nos fazer compreender o manuscrito, a autora também nos apresenta outras obras publicadas para crianças, no mesmo período, sendo elas: Contos Infantis (1986), de Adelina Vieira e Júlia Lopes de Almeida, e Livro das crianças(1987), de Zalina Rolim, tendo essa última sido aluna do autor. Essas obras são apresentadas através de trechos e fotos de algumas páginas dos livros, onde a autora busca aproximações e diferenças, como a estética-formal e as disposições e sentidos dados às estampas. 
Além dessas obras, a autora também traz textos, produzidos para outros livros/jornais, do próprio João Köpke.

Ao final dos cinco capítulos, Ferreira nos mostra, através de uma pesquisa histórica coerente com os pressupostos teóricos e metodológicos, João Köpke como um mestre-escritor preocupado em distinguir a fase infantil da fase adulta, não só pelos conteúdos, mas também pelas linguagens utilizadas. Um escritor que utiliza em seus poemas uma linguagem onomatopaica, musicada, ritmada e popular, própria do universo infantil.

A obra de Ferreira apoia-se na perspectiva da História Cultural (CHARTIER, 1990), fazendo-nos pensar o manuscrito de Köpke como objeto cultural possível de ser compreendido nas representações e práticas que eles movimentam, bem como fonte para a compreensão de aspectos da cultura escrita situada e datada histórica e culturalmente.

Uma obra bem estruturada, de fácil compreensão, com linguagem clara e sensível. O livro traz, ao final, a reprodução dos poemas do manuscrito "Versos para os pequeninos", o que nos induz a viajar para outra época, e cria a vontade de ter os manuscritos em mãos, para absorver toda a beleza e leveza com que o autor escreve. Sem dúvida, uma obra altamente recomendável para todos os professores, principalmente aqueles que buscam conhecer a história da alfabetização e da leitura no Brasil.

Recebido em: 04/07/2020

Aceito em: 24/08/2020 